\title{
Pokonać epidemię, czyli o dekadentyzmie w literaturze serbskiej (na przykładzie powieści Strast Davida S. Pijadego)
}

\author{
Abstract \\ To Defeat an Epidemic, or on Decadence in Serbian Literature (the Case of David S. Pijade's \\ Novel Strast)
}

Since its publication in 1921, David S. Pijade's Strast (The Passion) has been classified as a naturalist novel, contrary to its themes: passion as subordinated to the fatalism of nature: Eros and Thanatos, the hedonistic experience of an ,intense moment', the theme of sacred lesbian love. The article indicates that this classification is a mistake stemming from the lack of the decadent movement in Serbia, either as a literary current, or a worldview. A new reading proposed in this article calls for a revision of persistent views about the shape of Serbian modernism in the early twentieth century.

Key words: Naturalism, Decadence, Eros and Thanatos, femme fatale, homoeroticism, Serbian literature of the early twentieth century.

Słowa kluczowe: naturalizm, dekadentyzm, Eros i Tanatos, homoerotyzm, literatura serbska początku XX wieku.

W 1921 roku ukazała się powieść Strast (Namiętność) Davida S. Pijadego, mało znanego serbskiego poety i pisarza żydowskiego pochodzenia. Książka została odczytana przez pryzmat obowiązujących w czasach jej powstania norm obyczajowych jako skandalizująca, zaś przypisana jej wówczas etykieta jest przywoływana, bez żadnych zastrzeżeń, aż do dziś. Choć zapewne poruszana w dziele tematyka erotyczna, zwłaszcza zaś kwestie związane z miłością lesbijską, w czasach jego powstania mogły szokować odbiorców, to jednak nie ulega wątpliwości, że literackie opracowania ,motywu chuci” w latach 20. i 30. XX wieku, także w literaturze serbskiej, nie były zjawiskiem odosobnionym. Jak stwierdza Radovan Vučković, badacz serbskiej i chorwackiej literatury międzywojennej:

Znawca ówczesnych realiów literackich nie będzie miał większych problemów, by stwierdzić, że tematyka destrukcyjnej kobiecej rozwiązłości, patologicznej pasji erotycznej mężczyzny i zbiorowych orgii przyciaggała wtedy niemal wszystkich prozaików. Na początku 
XX wieku powstała wcześniej niespotykana liczba dzieł prozatorskich o lubieżnych i perwersyjnych kobietach, których destrukcyjna siła urasta do rangi symbolu. [...] Tematyka erotycznych uniesień była następstwem patologii i traumatycznych doświadczeń czasów wojny i powojnia, ale także intensywnej recepcji Freuda ${ }^{1}$.

Czynnikiem, który - jak się wydaje - wpłynął na klasyfikację Strasti jako powieści ,pornograficznej”, było niewłaściwe odczytanie intencji pisarza. Stworzył on bowiem tekst dekadencki, który przez czytelniczą publiczność został zinterpretowany na zasadzie nawyku, niejako automatycznie, jako tekst naturalistyczny, pomimo że temat miłości lesbijskiej pojawiający się w utworze w kontekście rozważań na temat ideału piękna rozumianego w sposób parnasistowski wyraźnie kłóci się ze światopoglądem naturalistycznym. Interesujący jest także tryb recepcji tego utworu na początku XX wieku i po II wojnie światowej. Chociaż współcześnie dzieło zostało ocenione negatywnie, określenia ,pornograficzne”, użytego przez Predraga Palavestrę ${ }^{2}$ oraz Stanka Koracia, który nota bene uważa, że podtytuł „Powieść z życia Belgradu" jest nieadekwatny do tematyki utworu ${ }^{3}$, nie spotykamy w (także niepochlebnych) omówieniach pierwszego wydania utworu ${ }^{4}$. Co więcej, w recenzji, która ukazała się w 1921 roku na łamach czasopisma „Zenit”, przez jego redaktorów powieść została, słusznie, usytuowana w nurcie erotycznym spod znaku symbolizmu i parnasizmu. W krótkiej prezentacji książki anonimowego autora czytamy m.in.: „S.D. Pijade jest pogrobowcem P. Louysa, M. Prevosta ${ }^{5}$, rodzonym bratem M. Begovicia. Dlaczego p. Pijade czytał właśnie takie książki? Być może lektura innych, licznych przecież, znakomitych dzieł urodziłaby lepszym płodem?"”.

Nie wiemy, czy David S. Pijade miał w ręku lektury wskazane przez recenzenta, natomiast o upodobaniach artystycznych i kulturze literackiej tego mało znanego autora dobitnie świadczy repertuar przetłumaczonych przez niego dzieł (o których z całą pewnością możemy powiedzieć, że dokładnie je przeczytał). Wśród nich znalazły się między innymi Portret Doriana Greya Oskara Wilde'a ${ }^{7}$ czy Przygody miłosne (Amours et aventures de Jacques Casanova de Seingalt) Giacoma Casanovy ${ }^{8}$, ale i poezja miłosna Rabindranatha Tagorego ${ }^{9}$, które niewątpliwie stanowią interpretacyjną podpowiedź dla sposobu odczytania Strasti, pomimo niepochlebnych opinii wznowionej w 2001 roku.

Typ erotyki pojawiający się w powieści Pijadego nie wpisywał się w duchową atmosferę czasów, w których dzieło powstało, o czym najlepiej świadczy na

${ }^{1}$ R. Vučković, Proza srpske avangarde, Beograd 2011, s. 45-46. Autorką thumaczeń cytowanych fragmentów na język polski, o ile nie wskazano innego nazwiska, jest Sylwia Nowak-Bajcar.

${ }^{2}$ Por. P. Palavestra, Jevrejski pisci u srpskoj književnosti, Beograd 1998, s. 97.

${ }^{3}$ S. Korać, Srpski roman između dva rata 1919-1941, Beograd 1982, s. 401.

${ }^{4}$ Por. K. Marinković, Predgovor [w:] D.S. Pijade, Strast, Zagreb 1921, s. 7-9.

${ }^{5}$ W recenzji pojawia się błąd literowy w inicjale imienia Antoine'a Prevosta, autora powieści Historia kawalera des Grieux i Manon Lescaut (Histoire du chevalier des Grieux et de Manon Lescaut) z $1731 \mathrm{r}$.

${ }^{6}$ Niepodpisany autor, „Zenit” 1921, nr 5, s. 12.

${ }^{7}$ O. Vajld, Slika Dorjana Greja, thum. D.S. Pijade, przedmowa M. Crnjanski, Beograd 1920.

${ }^{8}$ Đ. Kasanova, Ljubavne avanture, thum. z niemieckiego D.S. Pijade, Beograd 1922.

${ }^{9}$ R. Tagore, Gradinar, tłum. D.S. Pijade, Beograd 1923; R. Tagore, Pevačeve žrtve, thum. D.S. Pijade, b.m.w., b.r.w. 
przykład negatywna ocena wystawiona powieści Michaiła Arcybaszewa Sanin. Jej przekład ukazał się w Zagrzebiu podczas I wojny światowej ${ }^{10}$, trzy lata przed opublikowaniem Strasti (również w Zagrzebiu). W 1918 roku podpisany inicjałami Niko Bartulović w zagrzebskim czasopiśmie literackim „Književni jug”, które redagował wraz z Vladimirem Ćoroviciem, Ivo Andriciem i Branko Mašiciem, opublikował tekst dezawuujący wartość dzieła, szczególnie zaś polityczno-obyczajowy anarchizm, będący u Arcybaszewa odzwierciedleniem nastrojów rosyjskiej inteligencji po klęsce rewolucji 1905 roku. W recenzji można było między innymi przeczytać:

W wymiarze socjalno-etycznym Sanin oznacza rozwiązłość i wyrzeczenie się ideałów. Przyjaciele autora nazwali dzieło ewangelią okresu porewolucyjnego. Dlaczego, niczym głupcy, poświęcamy życie w imię tego, co nieosiaggalne, mając na wyciagnnięcie ręki wszelkie uciechy? Jest to hedonizm najniższych lotów. [...] Dzisiaj, kiedy seksualny, polityczny i socjalny saninizm doprowadził świat do katastrofy, dzisiaj, gdy każdy myślący i uczciwy człowiek admiruje ideały oraz wysokie morale, publikacja tej antyspołecznej i nieetycznej książki to nieporozumienie lub rutynowy cynizm. N.B. ${ }^{11}$

Tryb lektury i recepcji książki Pijadego nie został zweryfikowany do dziś. Autorka nowszego omówienia powieści, Jelena Panić, odtwarza opinie utrwalone w obiegu społecznym (teza o naturalistycznym charakterze dzieła; stwierdzenie, że proza epistolarna jest wyrazem intymizacji literatury), osadzając je w rozważaniach na temat Erosa i Tanatosa Zygmunta Freuda i Georges'a Bataille'a. Podparcie się myślą psychoanalityczną w celu wyjaśnienia motywacji bohaterki dzieła, choć zasadne, nie wzbogaca jednak zasadniczo wiedzy na temat generowanych przez powieść sensów i jej znaczenia. Interesującą próbę odczytania tej powieści podjęła Jelena Petrović, która odwołując się do teorii Judith Buttler, zanalizowała dzieło w perspektywie teorii gender. Pomimo niewątpliwego potencjału emancypacyjnego tej interpretacji, dzięki której zweryfikowane zostają naukowe tezy na temat codzienności, wyobrażeń oraz praktyk społecznych czy politycznych na początku XX wieku ${ }^{12}$, nadal nierozwiązana pozostaje kwestia literackiego nurtu, w którym powieść Pijadego powinna zostać umieszczona. Problem ten sprowadza się do pytania: dlaczego opinie na temat Strasti pochodzące z czasów powstania książki (parnasizm, symbolizm) oraz te wyrażone przez badaczy współczesnych (naturalizm) tak bardzo od siebie odbiegają, co więcej - są rozbieżne ${ }^{13}$.

Praktyka uporczywego sytuowania utworu w nurcie naturalizmu była i jest implikowana, jak się wydaje, faktem nierozpoznawania/nieuznawania w literaturze serbskiej dekadentyzmu jako literackiego prądu, pomimo że Radovan Vučković, zwracając uwagę na dominację w prozie okresu międzywojennego motywów

${ }^{10}$ M. Arcibašev, Sanjin, tłum. D.P. Đorđević, Zagreb 1917.

${ }^{11}$ N.B. [Niko Bartulović], M. Arcibašev: „Sanjin”, „Književni jug” 1918 (15.01.1918), nr 2, s. $86-87$.

12 J. Petrović, Homoseksualnost u romanima s početka 20. veka-emancipacijski potencijali jugoslovenske književnosti [w:] Među nama. Neispričana priče gej i lesbejskih života, red. J. Blagojević, O. Dimitrijević, Beograd 2014, s. 268-280.

13 J. Panić, Epistole između Erosa i Tanatosa (Strast Davida S. Pijade), „Godišnjak Katedre za srpsku književnost sa jugoslovenskim književnostima”, Filološkog fakulteta Univerziteta u Beogradu, god. IV, Beograd 2008, s. 207-219. Artykuł jest rozdziałem w książce: eadem, Grad $i$ strast: naturalistički elementi u srpskom modernističkom romanu, Beograd 2009, s. 93-110. 
erotycznych (u takich pisarzy, jak: Dragiša Vasić, Rastko Petrović, Borivoje Jevtić, Hamza Humo, Rade Drainac, Aleksandar Ilić), jako jeden z nielicznych historyków literatury serbskiej wywodzi ,[...] temat wyzwolonego destrukcyjnego erosa, którego nosicielką jest diaboliczna kobieta z dekadentyzmu lat 90. XIX wieku (dzieł Przybyszewskiego i Strindberga), który na początku XX wieku znajdował swoją manifestację w utworach Arcybaszewa"14. Znamienny jest fakt, że temat skłonności do tej samej płci nie zaistniał w literaturze serbskiej równolegle z pojawieniem się Wilde'a czy Rimbauda, ale - podobnie jak w literaturze polskiej ${ }^{15}$ - dopiero w okresie dwudziestolecia międzywojennego (powieść Pijadego wskazuje się jako pierwszy w literaturze serbskiej utwór w o tematyce eksplicytnie homoerotycznej). Zresztą trudności z możliwością potraktowania dekadentyzmu jako prądu literackiego mają nie tylko badacze w Serbii. Teresa Walas, podejmując trud jego pionierskiego opisu w literaturze polskiej, w swojej książce z roku 1986 stwierdza, że historycy literatury chętniej dostrzegają obecność postawy dekadenckiej aniżeli dekadentyzmu rozumianego jako prąd literacki czy „układ światopoglądowy" ${ }^{16}$. Fakt ten wynika nie tylko z braku umocowania dekadentyzmu w Polsce w refleksji filozoficznej czy intelektualnej (wyjątkiem jest Stanisław Przybyszewski), ale także, jak stwierdza krakowska badaczka, z faktu, „iż dekadentyzm, który chcemy traktować jako całość samodzielną i odrębną, jest nią do pewnego tylko stopnia, odwołuje się bowiem w sposób bardzo wyraźny do innej zamkniętej wypowiedzi światopoglądowej, a w części stanowi wyraźną jej transformację. Wypowiedzią tą jest światopogląd pozytywistyczno-naturalistyczny" ${ }^{17}$. Można więc uznać, że - jak stwierdza dalej T. Walas:

dekadenckie wyobrażenia o rzeczywistości i takież jej odczuwanie pojawia się w chwili, gdy światopogląd pozytywistyczno-naturalistyczny pozostaje w mocy jako jedyny prawdziwy i dla świadomości dostępny (przy czym elementy naturalistyczne istotniejsze są i lepiej widoczne), a równocześnie nie sprawia on już satysfakcji tej świadomości, a raczej uwiera i staje się dla niej powodem cierpienia, co prowadzi do uznania przez nią tego stanu za rodzaj obowiązującej prawdy o świecie, do sformułowania na jego gruncie nowej wypowiedzi światopoglądowej ${ }^{18}$.

Konstatacja krakowskiej badaczki jest dla sposobu odczytania powieści Pijadego niezwykle istotna. Rozpoznania literaturoznawczyni pozwalają na postawienie tezy, zgodnie z którą utwór serbskiego pisarza jest tekstem dekadenckim, spod którego przebija tekst naturalistyczny, zaś błędna klasyfikacja powieści to skutek działania społecznego tabu, które treści „nieakceptowalne” (homoseksualizm) usunęło w cień uwagi odbiorców. Podczas gdy interpretacyjne przedsięwzięcia, zapewne z powodów obyczajowych, całkowicie pomijały wątek lesbijski (który był ośrodkiem tekstu dekadenckiego, a nie naturalistycznego), to właśnie obec-

14 R. Vučković, op. cit., s. 45 i 39.

15 Zob. A. Czabanowska-Wróbel, Maski kobiety i twarz mężczyzny, „Teksty Drugie” 1993, nr 4/5/6, s. 187; W. Gutowski, Nagie dusze i maski (w młodopolskich mitach miłości), Kraków 1992, s. 222.

16 T. Walas, Ku otchłani (dekadentyzm w literaturze polskiej 1890-1905), Kraków-Wrocław 1986, s. 90.

17 Ibid., s. 34-35.

18 Ibid., s. 43-44. 
ność tego transgresyjnego wątku przyczyniała się do przypisania powieści miana „pornograficznej”, dezawuującego jej wartość i poddającego ją wykluczeniu.

Problematyka transgresji seksualnej nie jest w tej powieści punktem wyjścia i dojścia, lecz stanowi ośrodek dekadenckiego estetyzmu, z którym zderzony jest „stary” porządek światopoglądowy - tekst naturalistyczny. Jest on, dodajmy, w utworze wartościowany negatywnie: podporządkowanie się zasadom społecznym, które odwzorowują siły natury, popycha człowieka do „skoku w przepaść”, wiedzie zatem do nieuniknionej katastrofy (autodestrukcji, samobójstwa, śmierci), która jest z jednej strony aktem wymuszonym przez społeczeństwo, z drugiej zaś - przedmiotem pożądania. Skok „ku otchłani” - by posłużyć się tytułem pracy Teresy Walas - jest metaforą poddawania się opresyjnym nakazom społecznym i jednocześnie ulegania siłom natury (przedstawionym jako pożądanie heteroseksualne ${ }^{19}$ ) wbrew własnej woli. Głównym obiektem krytyki jest w powieści instytucja małżeństwa, w którym „Eros - wykastrowany z uczuć - podporządkowany został celom pragmatycznym i ekonomicznym: prokreacji i umacnianiu monogamicznej rodziny. Właściwie Eros zniknął - pozostało małżeństwo jako instytucja sankcjonowana intercyzą i prostytucja regulująca nadmiar seksualnej energii" ${ }^{20}$. Negatywna ocena mechanizmów społecznych, które - zgodnie z przekonaniami naturalistów - odwzorowują prawa natury, jest zarazem przejawem braku wiary Davida S. Pijadego w pozytywny, progresywny charakter społecznej „,ewolucji”, zaś ów sceptycyzm staje się podstawą wyrażonego w powieści światopoglądu dekadenckiego.

Bohaterką powieści Strast jest dziewczyna, która żyje w skonwencjonalizowanym świecie mieszczańskiego dobrobytu, odczuwa pustkę i nie potrafi znaleźć swojego życiowego celu, między innymi za sprawą poddania jej systemowi edukacyjnemu (jako 15-latka trafia do szkoły przyklasztornej). Odkryta przez Radmilę w klasztorze - miejscu pogłębiającym alienację i oderwanie od życia miłość do kobiety (fizyczna i duchowa transgresja bohaterki) stanowi odpowiedź jednostki, która w sytuacji kryzysu wartości usiłuje znaleźć własną, indywidualną strategię zachowania wobec świata wzbudzającego odrazę. Jej źródłem zaś są społeczeństwo oraz natura, a raczej społeczeństwo oparte na fundamentach światopoglądu naturalistycznego, który przypisuje kobiecie funkcję zgodną z biologicznym ,powołaniem”, determinując w ten sposób jej społeczną rolę.

Sprzeciw bohaterki wobec małżeństwa (oraz świata mieszczańskiego) jako instytucji przymusu (,Dzisiaj małżeństwo nie jest idealnym połączeniem dwóch dusz, o którym marzy i które ma nadzieję urzeczywistnić niewinne dziewczę; jest ono bezlitosną żelazną obręczą, ukutą z konwencji, przesądów i zabobonów"21) wynika z potrzeby przełamania ograniczeń skonwencjonalizowanego życia społecznego, do którego kobieta przygotowywana jest od najmłodszych lat. „Prag-

19 O historii dyskursu ,naturalnego”, za pomocą których homoerotyzm kobiecy był wykluczany poza społeczną ,normę”, m.in. poprzez przyznawanie kobiecie prawa do rozkoszy i odmawianiu prawa do miłości zob. M.-J. Bonet, Zwiąki miłosne między kobietami od XVI do XX wieku, tłum. B. Szwarcman-Czarnota, Warszawa 1997, s. 14.

20 W. Gutowski, Nagie dusze i maski (w młodopolskich mitach miłości), Kraków 1992, s. 22.

21 D.S. Pijade, Strast, Beograd 2001, s. 43. 
nęłam - stwierdza Radmila - poprzez pracę odzyskać to, czego pozbawiło mnie niewłaściwe wychowanie, chciałam być pożyteczna, ja, która dorastałam niepotrzebna nikomu, nudząc się i próżnując [podkreśl. - S.N.B.]"22. Krytyka ta motywowana jest także potrzebą szeroko rozumianego tworzenia, działania (,Chciałam - stwierdza bohaterka - w pracy odnaleźć zapomnienie i oparcie dla całkiem nowego życia, życia twórczego [podkreśl. - S.N.B.]" ${ }^{23}$ ) oraz jej potrzebami duchowymi i estetycznymi, co uwidacznia się we fragmencie: „Czy stare panny są gorsze od innych dziewcząt? Fakt, że nie wyszły za mąż, potwierdza tylko to, że cenią sobie wartości, że ważne jest dla nich to, z kim się wiążą. Mają swoje ideały, kierują się własnym upodobaniem, którego nie potrafią się wyrzec. Jeżeli stały się ofiarami, to jedyną winę za to ponosi środowisko, w którym żyją i z którego nie pozwala im się wyrwać brak odwagi" "24. Miłość lesbijska staje się w powieści rodzajem więzi nie tylko seksualnej, ale i duchowej, porozumieniem będącym formą oporu wobec heteroseksualności jako represyjnej instytucji politycznej, ujmowanej w kategoriach władzy, dominacji i przymusu, którą za współczesną badaczką Adrienne Rich można określić mianem ,lesbijskiego kontinuum”, oznaczającego ,doświadczenie bogatego życia wewnętrznego, bunt przeciwko męskiej tyranii, dawanie i otrzymywanie praktycznego i politycznego wsparcia, jeśli możemy je kojarzyć z oporem wobec małżeństwa"”25.

W powieści serbskiego pisarza ów aspekt społeczny/emancypacyjny/kontestacyjny transgresji seksualnej pogłębiony zostaje także o wymiar indywidualny/ duchowy/estetyczny - miłość lesbijska jest tu przedstawiona jako jedyna forma miłości prawdziwej, opartej na porozumieniu dusz. Jawi się ona niemal jako miłość mistyczna, idealna, czysta (pomimo złamania ślubów czystości i przykazań), zaś klasztor, gdzie dokonuje się inicjacja seksualna bohaterki, stanowi znak oderwania od rzeczywistości, innego - wyższego - wymiaru. Odcięcie miłości idealnej od świata codzienności jest nie tylko wyrazem indywidualistycznego wyobcowania, ale także symboliczną sakralizacją zakazanego uczucia, uświęceniem występku ${ }^{26}$. Jedynie kobieta, i to mniszka (!), jest w stanie docenić wartość przedstawicielki swojej płci, a lesbijska miłość cielesna jawi się jako niemal mistyczna więź ciał i dusz: „Moje życie uświęciła chwila, w której nasze ciała po raz pierwszy się zetknęły a dusze połączyła boska harmonia wiecznego uniwersum"27 - stwierdza bohaterka. Urzeczywistnienie takiej miłości w świecie świeckim, do którego po opuszczeniu klasztoru powraca Radmila, jest jednak, zdaniem jej ukochanej, Margity, niemożliwe. Według niej piękno przynależy do, innego niż codzienne życie, porządku: do porządku wolności:

22 Ibid., s. 119.

23 Ibid.

24 Ibid., s. 30.

25 A. Riche, Przymusowa heteroseksualność a egzystencja lesbijska, tłum. A. Grzybek, „Furia Pierwsza" 1999/2000, nr 4/5, s. 111-112.

${ }^{26}$ Por. Ch. Lane, The Crimes of Virtue and the Love of Aversion: Sade, Genet, and the Christian Right, „American Imago” 1996, nr 4, s. 325-351.

27 David S. Pijade, Strast, Beograd 2001, s. 57. 
Podczas gdy ja całkowicie wyrzekłam się tego świata - zwraca się mniszka do swojej ukochanej - ty do niego powróciłaś, oczekując, że da ci on to, czego nie może ci zapewnić: poznanie piękna. Piękno można pojąć, jedynie wykraczając poza codzienność, poza jarmarczny zgiełk i zamęt, który ludzie zwą życiem. Aby móc patrzeć na świat swobodnie, trzeba być wolnym. A ty nie jesteś: miliony cienkich niewidocznych nici wiążą cię z otoczeniem i krępują uniesienia twej duszy. Stąd nieukojony ból i ogarniająca cię straszliwa rozpacz. Skoro żyjesz wśród ludzi, zżyj się z nimi, bezwarunkowo i świadomie. Nie możesz mocno wrastać w ich świat, kierując ku nam swoje pragnienia ${ }^{28}$.

Miłość między kobietami jest w powieści Pijadego ucieleśnieniem idei piękna, szczęścia i dobra, staje się rodzajem artystycznego manifestu głoszącego ideę sztuki dla sztuki. Więź ta nie przynależy do sfery popędów, ma ona wymiar estetyczny, duchowy i etyczny. Jej transgresyjny charakter polega na - odwołując się do rozpoznań Élisabeth Badinter, francuskiej historyczki kultury i filozofki - konstytuowaniu wolności: „Dla lesbijki miłość jest ryzykiem i podbojem, a nie popędem. Jest to bezinteresowny akt, celowo prowadzący, w sensie społecznym, donikąd. Ustanawia on jednostkę, kierując ją ku wolności osiąganej przez wymknięcie się schematom narzucanym przez zbiorowość"29.

Wrażliwość na piękno i jego potrzeba przejawiają się także w narcyzmie bohaterki, który z jednej strony jawi się jako przejaw krytykowanego przez nią systemu edukacyjnego, przypisującego kobiecie zadania podsycające kobiecą „,próżność”30, ale z drugiej - jej estetyzmu, dzięki któremu możemy ją określić mianem dandyski. Estetyzm ów uwidacznia się w uwadze, jaką bohaterka poświęca swemu ciału, i zachwycie nad nim. Motyw analizy własnego wizerunku w lustrze ma swój odpowiednik na planie kompozycyjnym utworu: powieść ma konwencję epistolarną - tworzą ją listy Radmili pisane do Margity, w których przywoływane są zarówno wspomnienia z klasztoru, jak i obecne stany duchowe bohaterki. W ten sposób korespondencja z ukochaną staje się odbiciem narcystycznego ,ja” kobiety, opisuje jej mentalną rzeczywistość, która w akcie pisania zostaje poddana autokreacji, stając się, podobnie jak lustro, „,narzędziem rozdwojenia" ${ }^{31}$.

Nie na tym jednak wyczerpuje się repertuar ról, w które wciela się bohaterka. Idąc za poradami osób, które polecają jej zamążpójście jako antidotum na

${ }^{28}$ Ibid., s. 42.

${ }^{29}$ E. Badinter, Wprowadzenie [w:] M.-J. Bonet, op. cit., s. 14.

${ }^{30}$ Simon de Beauvoir wywodzi kobiecy narcyzm z przyczyn społecznych: „Kobieta nie ma dostępu do męskich rodzajów działalności. Ma zajęcia, ale nic nie czyni. Spełnia funkcje żony, matki, gospodyni, ale świat nie widzi w tych funkcjach indywidualności kobiety. Prawda mężczyzny jest w domach, które buduje, w lasach, które karczuje, w chorych, których uzdrawia. Kobieta - nie mogąc się spełnić w projektach i celach - usiłuje się uchwycić w immanencji własnej osoby. [...] Wiele kobiet ogranicza krąg swoich zainteresowań do własnej osoby, doprowadzając do przerostu tej osoby, tak aby się zlała ze wszystkim - czynią zaś tak właśnie dlatego, że są niczym. «Jestem swoją własną bohaterką» - wyraziła się Maria Baszkircew. Mężczyzna, działając, konfrontuje się nieustannie z samym sobą. Kobieta, wyodrębniona ze społeczeństwa, nieskuteczna w działaniu, nie może się ani ustosunkować do świata, ani zmierzyć własnego znaczenia. Nadaje sobie najwyższą wagę, ponieważ nie ma dostępu do żadnego poważnego przedmiotu działania. Może zaś siebie samą uznać za cel własnych pragnień dlatego, że od dzieciństwa widzi siebie jako przedmiot”. S. de Beauvoir, Druga płeć, tłum. G. Mycielska, M. Leśniewska, Warszawa 2003, s. 683-684.

${ }^{31}$ Ibid., s. 686. 
cierpienie, nie mogąc urzeczywistnić swoich rozbudzonych pragnień o szczęściu i pięknie, wychodzi ona za mąż (rzuca się w przepaść życia). Postępuje zgodnie z oczekiwaniami społecznymi, ale czyni to, kontestując małżeństwo, odwracając przypisane kobiecie i mężczyźnie społeczne role. Odmawiając fizycznej miłości nie tylko mężowi, ale także ubiegającym się o jej względy zakochanym w niej adoratorom, czyni ze swego pięknego, budzącego pożądanie ciała narzędzie, za pomocą którego sprawuje nad nimi władzę.

Wstrzemięźliwość seksualna bohaterki to z jednej strony wyraz tęsknoty za transcendencją (negacja pierwiastka cielesnego), ale także przejaw żądzy panowania nad światem męskim i poniżenia go (poprzez uczynienie $\mathrm{z}$ ciała narzędzia kontroli). To pragnienie władzy czyni z niej kobietę fatalną, modliszkę, w figurze której mieszczą się piękno, zło i okrucieństwo („kallokagatia na wspak”32). Radmila dręczy kochających ją mężczyzn, odmawia im siebie, by w końcu ulec odrażającemu, prostackiemu i prymitywnemu subiektowi, podwładnemu swojego męża, będącemu całkowitym zaprzeczeniem jej wyobrażeń o wzniosłym pięknie i miłości. Wbrew swojej woli bohaterka ulega pragnieniu, biologicznemu popędowi, w sposób symboliczny powracając do świata natury. Jedyną zaś formą ucieczki z niego staje się kolejna transgresja - zabójstwo znienawidzonego kochanka i odebranie sobie życia, będące spełnieniem zaanonsowanego przez bohaterkę na początku powieści pragnienia śmierci:

Kiedy stałam pochylona nad przepaścią, przemknęła mi przez głowę myśl: co stałoby się, gdybym skoczyła? Ta myśl, kiełkująca w moim umyśle, przeistoczyła się w pragnienie, w przepełniającą mnie straszliwą żądzę. Nie, nie był to zawrót głowy, moja świadomość nigdy wcześniej nie była tak czysta. Drżałam z podniecenia. Odczuwałam nieopisaną błogość, rodzaj niepohamowanej radości. [...] Pęd ku błękitnej głębi niepojętej tajemnicy śmierci jest największą rozkoszą jaką może odczuwać żywa istota. Spadać, odczuwając w sercu słodki lęk, mocno zaciskając powieki, ze zmąconą świadomością, niczym w słodkim śnie... ${ }^{33}$

Posługując się klasyfikacją Wojciecha Gutowskiego, można stwierdzić, że w powieści zostały zaprezentowane dwa style zmysłowości: „apolliński spokój zachwytu wywołanego cielesnością", którego realizacją jest miłość lesbijska zmysłowość estetyzująca, izolująca i chroniąca Erosa w sferze sztuczności, reprezentująca negację rzeczywistości ziemskiej, zmysłowo-duchowa harmonia w przestrzeni izolowanej od życia - oraz naturalna, ,,szczera zmysłowość”, upojenie, „dionizyjskie szaleństwo"34 , będące realizacją jedności Erosa i Tanatosa. Obydwa wskazane w powieści typy erotyzmu, choć zostały przez autora Strasti zderzone z sobą na zasadzie przeciwieństwa: miłość twórcza/idealna/duchowa miłość destrukcyjna/oparta na żądzy/cielesna, nie dają się jednak rozpoznać jako „naturalistyczne”. Czerpią one bowiem ze stworzonej przez Baudelaire'a koncepcji erotyzmu, opierającej się na polemice z ideą Natury (i ludzkich pragnień) utożsamianej z dobrem. Stworzona przez francuskiego poetę ideologia piękna, opierająca się na negacji tego, co instynktowne i nieświadome, waloryzowała po-

32 M. Podraza-Kwiatkowska, Młodopolska femina: garść uwag, ,Teksty Drugie” 1993, nr 4/5/6, s. 46.

33 D.S. Pijade, Strast, Beograd 2001, s. 37-38.

34 W. Gutowski, Hedonizm młodopolskiej erotyki, „Pamiętnik Literacki” 1990, t. 81, z. 4, s. 106. 
zytywnie to, co przefiltrowane przez intelekt, wtórne i w tym sensie ,sztuczne" ${ }^{\text {35 }}$. Dlatego też skłonność do autokreacji, znajdująca wyraz zarówno w narcyzmie, jak i w ,perwersjach”: oziębłości, wyniosłości i pogardzie dla mężczyzn, diabolicznej przewrotności i upajaniu się świadomym upadkiem, oddala bohaterkę powieści Pijadego od świata natury.

Można zatem stwierdzić, że światopogląd naturalistyczny jest w powieści tekstem, z którym autor polemizuje, wykorzystując w tym celu rekwizytorium najróżniejszych transgresji, charakterystycznych dla dekadentyzmu: mit chuci, podporządkowany fatalizmowi natury (sprzężenie Erosa i Tanatosa), hedonistyczny mit intensywnej chwili, mit lesbijski sakralizujący miłość zakazaną oraz mit kobiety fatalnej ${ }^{36}$. Zderzając z sobą dwa modele: miłosne uczucie (które dojrzewa w wyizolowanej od świata, zamkniętej przestrzeni klasztoru) i przyziemność nieokiełznanego instynktu seksualnego, od którego nie sposób się uwolnić, autor pokazuje pewną społeczną i artystyczną niemożność, utopię świata zbudowanego na estetyzmie, łączącego w jedno miłość, piękno i dobro. Motyw pożądania, na którym oparł swój utwór Pijade, ma charakter „,dekoracyjny”, „usztuczniający”. Celem zaś tego zabiegu jest wyraźne zdystansowanie się od naturalizmu. Jak zauważa Wojciech Gutowski, opisując młodopolskie wzorce erotyki, „,estetyzujący hedonizm był jednym $\mathrm{z}$ etapów znamiennego dla epoki procesu oddalania doświadczeń miłosnych od Natury (oraz od akceptowanych społecznie związków interpersonalnych) i przenoszenia ich w krainy sztuki (gdzie królował egotyzm, fascynacja partnerem uprzedmiotowionym) i w wersji najśmielszej - perwersji spajającej w jedność przeżyć Eros i Tanatos"37.

Temat pożądania (w jego wymiarze zarówno duchowym, jak i biologicznym) służy zatem Pijademu do konfrontacji dwóch perspektyw: podszytego mizoandrią kobiecego lęku przed dominacją mężczyzny i przed zagrażająca jej duchowości sferą życia seksualnego oraz z drugiej strony - uwzględniając fakt, że autorem powieści jest mężczyzna - podszytego mizoginią męskiego strachu przed demoniczną kobiecością. Przesłanie powieści, wyrażające myśl, że konfrontacja płci, ów motywowany pożądaniem-nienawiścią pojedynek, wiedzie ku otchłani, wywieść możemy z innej artystycznej inspiracji - z zamieszczonego w Kwiatach zła Baudelaire'a liryku Duellum, powstałego pod wpływem płótna Bitwa amazonek Rubensa:

Dwaj rycerze się zeszli, skrzyżowali szpady,

Rozpryskując dokoła i krew, i błyskania.

- Ta szermierka, szczęk broni - to przecież są zwady

Młodości, która padła łupem pożądania.

Broń prysła - niczym młodość, nasza młodość dziecko,

Niestety! Ale zęby i okrutne szpony

Wnet pomściły żelazo, tę klingę zdradziecka.

- O szale serc dojrzałych, miłością zranionych!

${ }^{35}$ Ch. Baudelaire, Malarz życia współczesnego [w:] idem, O sztuce. Szkice krytyczne, wybór i tłum. J. Guze, wstęp J. Starzyński, Wrocław-Warszawa-Kraków 1961, s. 223-224.

${ }^{36}$ W. Gutowski, Nagie dusze i maski..., s. 16.

${ }^{37}$ W. Gutowski, Hedonizm młodopolskiej erotyki..., s. 118. 
W rozpadlinę, gdzie czają się rysie i sowy,

Skrapiając ciernie krwi swej szlakiem purpurowym,

Dziko zwarci staczają się antagoniści.

Znajdziemy naszych bliźnich na dnie tego piekła.

Stoczymy się tam bez żalu, amazonko wściekła,

By uwiecznić żarliwość naszej nienawiści! ${ }^{38}$

Wskazanie artystycznych źródeł powieści Pijadego nie przynosi jednak odpowiedzi na pytanie o intencje autorskie, które pozostają otwarte: czy powieść jest uzasadnieniem wysiłków kobiety, za pomocą różnorodnych strategii transgresyjnych pragnącej zdobyć prawo do uczucia, którego (w ówczesnych warunkach społecznych) nie dawało małżeństwo, by w ten sposób wedrzeć się do świata zarezerwowanego dla mężczyzn - do sfery kultury, czy też wyrazem strachu przed zemstą kobiet za przypisaną im przez mężczyzn rolę wygnańca do świata natury? Czy kobiecy portret nakreślony w Strasti odtwarza stworzony w XIX wieku negatywny stereotyp lesbijki jako kobiety upadłej, czy stanowi próbę wskazania społecznych przyczyn tego upadku, jego uzasadnienie?

Prezentacja problematyki powieści, ujętej przez autora w schematyczne i bardzo rozpoznawalne z punktu widzenia polskiego czytelnika stereotypowe schematy, wyraźnie wskazuje, że dzieło wykracza poza przypisaną mu etykietę naturalizmu. Przyczyn zaś tego faktu należy upatrywać w negatywnej recepcji dekadentyzmu w Serbii, do czego z całą pewnością przyczyniło się przypisane dekadentyzmowi miano „literackiej epidemii”. Autor tej diagnozy, profesor Uniwersytetu w Belgradzie i niepodważalny autorytet w dziedzinie literatury pięknej, Jovan Skerlić, niezwykle skutecznie przyczynił się do wyeliminowania dekadentyzmu z literackiego słownika terminów pożądanych, gdy w 1909 roku, witając nieśmiałe poetyckie oddźwięki tego nurtu, czy - jak sam to ujął - „parafrazy” poezji Baudelaire'a, pisał:

Dekadentyzm był odrażającą i podstępną chorobą, która opanowała Europę, a ustąpiwszy, pozostawiła po sobie wspomnienie czegoś szarlatańskiego, szpetnego i jałowego. Jaki jest sens, by, z typową kobiecą bezmyślną skłonnością do ulegania modom, tą pokonaną już chorobą starych, wyczerpanych i zmęczonych, bardziej rozwiniętych i bogatszych literatur infekować naszą młodą i świeżą rasę, nasze „promienne Południe”, tchnące słońcem i pogodą ducha, naszą młodą literaturę, będącą w pełni swoich twórczych sił, której źródło tryska zdrowiem i witalnością? ${ }^{39}$

Historia recepcji powieści Strast Davida S. Pijadego potwierdza konieczność podjęcia badań, które umożliwią weryfikację utrwalonych i powielanych bezrefleksyjnie sądów na temat literatury serbskiej początku XX wieku. Być może umożliwią one dostrzeżenie nieznanego dotąd oblicza serbskiego modernizmu.

${ }^{38}$ Ch. Baudelaire, Duellum, tłum. M. Leśniewska [w:] idem, Kwiaty zła, wyb. M. Leśniewska, J. Brzozowski, red. i posłowie J. Brzozowski, Kraków 1991, s. 95.

39 J. Skerlić, Jedna književna zaraza, „Srpski književni glasnik” 1909, knj. XXII, nr 8, s. 597-598. 


\section{Bibliografia}

Arcibašev M., Sanjin, tłum. D.P. Đorđević, Zagreb 1917.

N.B. [Niko Bartulović], M. Arcibašev: ,,Sanjin”, „Književni jug” 1918 (15.01.1918), nr 2, s. 86-87.

Baudelaire Ch., Kwiaty zła, wyb. M. Leśniewska, J. Brzozowski, red. i posłowie J. Brzozowski, Kraków 1991.

Baudelaire Ch., O sztuce. Szkice krytyczne, wyb. i tłum. J. Guze, wstęp J. Starzyński, Wrocław-Warszawa-Kraków 1961.

de Beauvoir S., Druga płeć, tłum. G. Mycielska, M. Leśniewska, Warszawa 2003.

Bonet M.-J., Związki miłosne między kobietami od XVI do XX wieku, tłum. B. Szwarcman-Czarnota, Warszawa 1997.

Czabanowska-Wróbel A., Maski kobiety i twarz mężczyzny, „Teksty Drugie” 1993, nr 4/5/6, s. 184-189.

Gutowski W., Hedonizm młodopolskiej erotyki, „Pamiętnik Literacki” 1990, t. 81.

Gutowski W., Nagie dusze i maski (w młodopolskich mitach miłości), Kraków 1992.

Kasanova Đ., Ljubavne avanture, tłum. z niemieckiego D.S. Pijade, Beograd 1922.

Korać S., Srpski roman između dva rata 1919-1941, Beograd 1982.

Lane Ch., The Crimes of Virtue and the Love of Aversion: Sade, Genet, and the Christian Right, „American Imago” 1996, nr 4, s. 325-351.

Palavestra P., Jevrejski pisci u srpskoj književnosti, Beograd 1998.

Panić J., Epistole između Erosa i Tanatosa (Strast Davida S. Pijade), „Godišnjak Katedre za srpsku književnost sa jugoslovenskim književnostima”, Filološkog fakulteta Univerziteta u Beogradu, god. IV, Beograd 2008, s. 207-219.

Panić J., Grad i strast: naturalistički elementi u srpskom modernističkom romanu, Beograd 2009.

Petrović J., Homoseksualnost u romanima s početka 20. veka-emancipacijski potencijali jugoslovenske književnosti [w:] Među nama. Neispričana priče gej i lesbejskih života, red. J. Blagojević, O. Dimitrijević, Beograd 2014, s. 268-280.

Pijade D.S., Strast, Beograd 2001.

Pijade D.S., Strast, Zagreb 1921.

Podraza-Kwiatkowska M., Młodopolska femina: garść uwag, „Teksty Drugie” 1993, nr 4/5/6, s. 36-53.

Riche A., Przymusowa heteroseksualność a egzystencja lesbijska, thum. A. Grzybek, „Furia Pierwsza” 1999/2000, nr 4/5.

Skerlić J., Jedna književna zaraza, ,Srpski književni glasnik” 1909, 16 kwietnia 1909, knj. XXII, nr 8, s. 589-598.

Tagore R., Gradinar, tłum. D.S. Pijade, Beograd 1923.

Tagore R., Pevačeve žrtve, thum. D.S. Pijade, b.m.w., b.r.w.

Vučković R., Proza srpske avangarde, Beograd 2011.

Vajld O., Slika Dorjana Greja, thum. D.S. Pijade, przedmowa M. Crnjanski, Beograd 1920.

Walas T., Ku otchłani (dekadentyzm w literaturze polskiej 1890-1905), KrakówWrocław 1986. 
